JULIÁN MEZA

\title{
La imbecilidad binaria
}

\begin{abstract}
"Todos los hombres son bellos" es una proposición improbable estéticamente; que cada uno sea susceptible de volverse bueno es un objeto de fe y, por lo tanto, de impugnación; pero que todos sin excepción estamos en condiciones de revelarnos como idiotas no acepta la menor discusión: el hombre es el único animal capaz de volverse una bestia.
\end{abstract}

André Glucksmann: La bêtise

FIGURA DESTACADA DEL siglo XX, el imbécil aparenta, sin embargo, no estar presente. Directa e indirectamente afirma con obstinación su ausencia en los hechos y pensamientos que circulan por los escenarios en donde hoy se escribe el pequeño y gran teatro del mundo. No obstante su capacidad para hacerse invisible dondequiera que hace acto de presencia, el imbécil está con nosotros. Se halla oculto tras las candilejas que iluminan la pirotecnia de nuestras guerras. Se esconde bajo las máscaras que dan vida al carnaval de los conocimientos caros a nuestro querido siglo. El imbécil atraviesa el proscenio y se disimula tras las bambalinas del escenario, de todos los escenarios frente a los cuales, apoltronados en nuestros sillones, o rígidos en nuestras sillas reímos, lloramos, aplaudimos... estúpidamente.

Más allá del chiste, del gesto obsceno; más allá del simulacro dramático y de la comedia sin risa; más allá de la pomposa oratoria y de la demoledora solemnidad del maestro de ceremonia, ¿qué podemos ver en el escenario?

El imbécil es el amo en política nacional y extranjera. Desem- 
peña alegremente su papel en las Cámaras y en las antesalas de los ministerios y de los organismos internacionales. Es príncipe y ujier, funcionario y público. El idiota hace discursos, puntualiza, aconseja, advierte y opina; oye discursos, permite que le saturen los oídos con perogrulladas, se deja aconsejar, calla, concede. Halla la confirmación de su papel en los hechos que sepultan a las palabras, maltratan a las opiniones, desvirtúan los consejos y hacen caso omiso de las advertencias.

El imbécil es el amo en las cosas que tienen relación con el pensamiento y en aquellas donde pensar es ausentarse. Se divierte en la cama y barre con todo a la mesa. Se atraganta, se embriaga, bosteza y ronca. Conduce un pequeño o un enorme vehículo. Es gritón y sumiso. Se queja. Hace cola y lame traseros. Prepotente o impotente, el imbécil frecuenta la vida cotidiana y asiste puntual a los grandes acontecimientos disfrazado de guarura o de terrorista. Tanto en las relaciones entre los hombres, como entre los hombres y las cosas el imbécil es el soberano. Gobierna las querellas y los amorios. Así en la paz como en la guerra tiene todas las armas, controla todos los poderes. Si en política no puede ser vencido, en los asuntos del corazón y del sexo no es menos inexpugnable.

$¿$ De dónde procede este embargo omnipresente que lleva a cabo la imbecilidad?

Aun cuando parece ser sólo Uno, el imbécil siempre suma dos. ¿ Dialéctica del amo y el esclavo? No: el imbécil es, a la vez, el amo y el esclavo, el tirano $y$ el tiranizado, el sádico $y$ el masoquista: “...en et caso del amor como en el de la crueldad, se requieren dos que congenien mutuamente" (Robert Musil, Sobre la estupidez).

En ausencia de la dialéctica, a falta de una síntesis que lo anularía, el imbécil es, uno tras otro, el amo y el esclavo, jacques y su amo. El idiota es el amo en política $y$ el esclavo en amores... o viceversa. Gana ahí donde los demás pierden; pierde donde los otros ganan.

Es verdad que en ocasiones es al mismo tiempo el amo en politica y en amores: canciller y Don Juan; pero a fuerza de ganar acumula tantas imbecilidades que su victoria se vuelve pírrica.

Otros imbéciles tienen la costumbre de perder siempre; pero a fuerza de tanto perder a su modo resultan ganadores. ¿Acaso cuando pierden en amores con el tiempo no salen ganando? De derrota en derrota, los hombres y mujeres políticos ¿acaso no ganan finalmente en vida personal y se vuelven menos idiotas? ¡Mi reino por una bata y un par de pantuflas!

No es requisito ser amo $o$ esclavo para ser idiota. La estupidez no tiene la costumbre de respetar las jerarquías. Ninguna clase social 
está al abrigo de la imbecilidad. La tontería se aloja en lo alto y en lo bajo de la escala social. Además, adora los puntos intermedios. Vive feliz a diestra y siniestra. No ocupa un lugar privilegiado en el abanico de las ideologías.

En el plano de lo político la izquierda y la derecha se miran tontamente frente a frente. $\mathrm{Y}$ así se miden. No hay ninguna acción emprendida por una de ellas que no sea automática e inmediatamente mimetizada por la otra. Frente a la imbecilidad de la televisión adiestrada prorrumpe majestuosa la imbecilidad de la televisión siniestrada. Si el Ku Klus Klan lincha negros, la izquierda bienpensante lincha poetas. Frente a los campos de concentración de la derecha se erigen los de la izquierda. Contra tu mentira, la mía y, como siempre, viceversa.

Cuando un periodista aplaude la liquidación de quince soldados al servicio de un dictador latinoamericano por un comando de guerrilleros (que prefiguran otro dictador), otro periodista como él aplaude la liquidación de quince guerrilleros por soldados del mismo dictador. Thanatos tiene hijos en todos los bandos. Reñidas en lo ideológico, izquierda y derecha se dan la mano en la estupidez. Su programa común de la estupidez son las cifras: quince puntos para cada bando y dejemos de lado la identidad de los muertos. Las cosas parecen empeorar cuando la imbecilidad asciende un escalón en su búsqueda de "la solución final" y hace el balance: en total, 3000 muertos para ti y 3000 muertos para mí. ¡Empatados!

¿ Podría hallarse un grado de imbecilidad mayor? Difícilmente. La imbecilidad no se cifra y, en este punto, no cuenta hasta dos. Un muerto es un muerto, sea de derecha o de izquierda. Shakespeare ya había dicho algo al respecto. ;Peor para Shakespeare!

$¿$ ¿uién gana entonces? En el terreno específico de la estupidez siempre hay empate $y$, por lo mismo, resulta dificil otorgar premios. Izquierda y derecha se descubren como insuperables competidores en su imbecilidad.

¿Qué se puede hacer, entonces, frente a la imbecilidad? ¿Cómo escapar a esta hipoteca creciente que pesa cada vez más sobre el Siglo XX? Dándole la cara, aceptando la parte que nos corresponde sin pensar, tontamente, que algún día nos hallaremos plenamente fuera de su alcance.

Es inútil querer defenderse de ella. Todos y cada uno llevamos (bien o mal) en nosotros mismos la parte de la imbecilidad que nos corresponde. Y dado que la imbecilidad es binaria y nosotros no somos unitarios será infructuoso querer jugar con ella a las escondidas. Tarde o temprano, la imbecilidad nos encuentra. 
Un punto de partida para que tal vez la imbecilidad no nos aplaste: aceptarla en nosotros mismos. Quizá sólo así no hará de nosotros sus víctimas enteramente.

Dos filósofos - probablemente no demasiado imbéciles- nos muestran el camino hacia el reconocimiento de nuestra propia imbecilidad... antes de querer hurgar en la de aquellos a los que demasiado pronto tachamos de imbéciles.

Descartes (que tal vez fue un poco ligero al afirmar que el sentido común es la cosa más compartida del mundo), nos instruye por la negativa: sería deseable el uso del sentido común en todos lados y lo más a menudo posible. Se trata, pues, de un deseo que probablemente no convendría tomar por la realidad. $Y$ la realidad es que, en ausencia del sentido común, la imbecilidad es la cosa más compartida del mundo.

Aun cuando en el siglo XX parece llevarse a cabo una escalada de la imbecilidad, la estupidez no es nuestra de manera exclusiva. La tontería es dueña del mundo desde los orígenes. No es raro. por lo tanto, que Sócrates haya sido el primero en recordárnoslo. Su "conócete a ti mismo" sugiere, es posible: "sé que ignoras", o más sutil y profundamente: "conoce al imbécil que hay en ti", pues él es tu peor enemigo, tu demonio, la sirena que te posee con su canto, la bruja que te hechiza con sus encantamientos. Tal vez de esta manera la imbecilidad a la que no escapamos tampoco se nos escape y tengamos la posibilidad de ver en lo que dice Sócrates no un conocimiento definitivo, ni menos aún una certidumbre, sino un espacio en el que las imbecilidades de todo tipo y a todos los grados imaginables tejen un campo propicio a la risa, al llanto, a la cólera y a la reflexión.

Pero, $¿$ de dónde proceden esta líneas? ¿ ¿ De dónde viene la voluntad de intentar algo tan dificil como una reflexión sobre la imbecilidad?

En un libro muy reciente, del que no tengo la intención de hacer una reseña ${ }_{(} \dot{\text { de }}$ qué serviría una invitación a su lectura si pasará algún tiempo antes que sea asequible en español?), André Glucksmann (La bêtise, Ed. Grasset, París, 1985, 274 pp.) se libra a una reflexión sobre la imbecilidad sin la pretensión de subestimarla. Este libro sugiere algunas de las ideas que motivan estas líneas.

De cara a la imbecilidad hay maneras y maneras. Hay incluso posturas... no todas ellas muy cómodas. La imbecilidad es, por ejemplo, fuente de risa, ya sea porque nos hacer reír, o porque es la causa de que se rían de nosotros: el otro recibe un pastelazo en la cara, o somos nosotros los que lo recibimos. El pastelazo, entonces, nos sitúa frente un estilo burlesco de vislumbrar la vida, el amor, la política. 
De la risa de Aristóteles a la de Kafka, de la de Buster Keaton a la de Peter Sellers el pastelazo es una medida que tal vez no sea demasiado idiota.

La imbecilidad humana me hace llorar. Yo provoco el llanto con mi imbecilidad. Ningún otro llanto es posible. Pero no hay que exagerar: no corremos el riesgo de anegarnos en lágrimas ante tanta imbecilidad. Campos de exterminio y de concentración hacen llorar... al menos a aquellos a los que su imbecilidad no se los impide.

En ausencia de las lágrimas hace acto de presencia la cólera: un peligroso personaje que nos vuelve locos y puede llevarnos a cometer mayores imbecilidades.

Cuando jugamos a que somos Bouvard al volante de un automóvil, o Pecuchet al frente de un auditorio corremos el riesgo evidente de ser todavía más imbéciles que los otros.

La larga marcha de la imbecilidad es interminable. Ninguna enumeración le pone un término. Sus potancialidades son infinitas. También lo son sus maneras. Sin ánimo de agotarla, pues es infatigable, tal vez valga la pena hacer una última parada en su recorrido y hablar francamente de la imbecilidad que no quiere ser imbécil.

Existe, es evidente, la imbecilidad imbécil que no se niega a mostrarse, a la que todo el mundo puede reconocer a primera vista y obsequiarle aunque sea una mirada -exceptuando aquellos que son demasiado imbéciles, tal vez por temor a reconocerse en ella. Hay, sin embargo, al lado de la imbecilidad imbécil, otra imbecilidad menos evidente: la del sabio e inteligente que supone saberlo todo y, por lo tanto, jamás cree ser imbécil. ¡ Cuidado con esta imbecilidad!, pues es ella la que no ha sabido ahorrarnos nuestra riqueza en megatones como promesa, ni millones de muertos como hechos consumados.Desde el vórtice de su locura, esta imbecilidad amenaza y, lo que es peor, cumple. $Y$ de aquí las incómodas posturas que desembocan en la imbecilidad que opta por la esclavitud ante la amenaza de muerte y se permite vociferar: "primero rojos que muertos" como única manera de sustraerse al apocalipsis nuclear. En ausencia de sentido común nada más fácil que fingir sentido común. ¿ No hay, entonces, salida frente a la imbecilidad?

Es dificil responder a esta pregunta, positiva o negativamente. Pero más allá del intelectual comprometido que habla de humanidad sin percatarse de la inhumanidad, más allá del concierto de voces que entonan loas a la servidumbre voluntaria y a las esclavitudes modernas, tal vez sea posible seguir rebelándose contra la mentira, continuar interrogándose acerca de todo, confesar nuestras propias debili- 
Notas

dades. Tal vez sólo así puedan tener algún sentido estas palabras de Rilke: "Lo que finalmente nos salva es no tener abrigo". 